NOTE

\title{
Batrachochytrium dendrobatidis detected in Kihansi spray toads at a captive breeding facility (Kihansi, Tanzania)
}

\author{
Mariam Makange1 ${ }^{1}$, Neema Kulaya1 ${ }^{1}$ Emiliana Biseko ${ }^{1}$, Parson Kalenga ${ }^{2}$, \\ Severinus Mutagwaba ${ }^{2}$, Gerald Misinzo ${ }^{1, *}$ \\ ${ }^{1}$ Department of Veterinary Microbiology and Parasitology, Faculty of Veterinary Medicine, \\ Sokoine University of Agriculture, Morogoro, Tanzania \\ ${ }^{2}$ Kihansi Research Station, Tanzania Wildlife Research Institute, Mlimba, Tanzania
}

\begin{abstract}
The chytrid fungus Batrachochytrium dendrobatidis $(B d)$ is the aetiological agent of amphibian chytridiomycosis, a disease associated with global amphibian population declines. In November 2012, mass mortalities of Kihansi spray toads Nectophrynoides asperginis were observed at the Kihansi captive breeding facility, located in the Udzungwa Mountains, Tanzania. Mortalities increased rapidly, and dead toads showed typical clinical signs of chytridiomycosis, including reddening of the skin that was especially evident on the toe pads. Treatment of toads with itraconazole rapidly reduced mortalities. Dead toads $(n=49)$ were collected and used to perform $B d$-specific polymerase chain reaction and subsequent nucleotide sequencing. All toads collected at the facility were positive for $B d$. The obtained $B d 5.8 \mathrm{~S}$ rRNA gene and flanking internal transcribed spacer regions (ITS1 and ITS2) were not $100 \%$ identical to any other $B d$ sequences in GenBank, but closely resembled isolates from Ecuador, Japan, USA, Brazil, Korea, and South Africa. To our knowledge, this is the first study reporting molecular characteristics of $B d$ isolated from the Udzungwa Mountains. Strict biosecurity measures at the breeding facility and in Kihansi spray wetlands where toads have been reintroduced have been implemented. Further studies on $B d$ epidemiology in the Udzungwa Mountains are recommended in order to understand its origin, prevalence, and molecular characteristics in wild amphibian populations. This will be important for conservation of several endemic amphibian species in the Udzungwa Mountains, which are part of the Eastern Arc Mountains, a global biodiversity hotspot.
\end{abstract}

KEY WORDS: Chytridiomycosis $\cdot B d \cdot$ Itraconazole $\cdot$ Nectophrynoides asperginis $\cdot 5.8 \mathrm{~S}$ rRNA Internal transcribed spacer region

Resale or republication not permitted without written consent of the publisher

\section{INTRODUCTION}

The Kihansi spray toad (KST) Nectophrynoides asperginis is a small-sized (snout-vent length: $10-18 \mathrm{~mm}$; body mass: $0.45-0.66 \mathrm{~g}$ ) ovoviviparous bufonid that was first recorded in the Kihansi spray wetlands in 1996 (Poynton et al. 1998, Lee et al. 2006). The spray wetlands in the Kihansi gorge are generated by falls of the Kihansi River along the steep edge of the eastern escarpment of the southern Udzungwa Mountains in Tanzania (Channing et al. 2006). At the time of species description and immediately afterwards, the KST was classified as Critically Endangered due to its restricted geographical range and the 
decreased water flow caused by the commissioning of the Lower Kihansi Hydropower Project (Poynton et al. 1998, Channing et al. 2006). The loss and modification of habitat and associated toad population fluctuations led to the translocation of 499 toads from the Kihansi spray wetlands to zoos in the USA in 2000 (Krajick 2006, Lee et al. 2006). Mass mortalities of toads were observed in 2003, leading to a crash in the wild toad population by early 2004, with the last sighting of toads recorded in 2005 (Weldon \& du Preez 2004, Krajick 2006). Currently, the KST is considered Extinct in the Wild, but the species survives in captivity at the Wildlife Conservation Society's Bronx Zoo and the Toledo Zoological Society, and at Kihansi and the University of Dar es Salaam captive breeding facilities in Tanzania (Krajick 2006, Channing et al. 2009). Attempts to re-introduce the KST to its natural habitat in the Kihansi spray wetlands have been underway since 2012 (www.iucn.org).

The amphibian disease chytridiomycosis, caused by the fungus Batrachochytrium dendrobatidis $(B d)$ together with stress due to drought caused by the failure of the artificial sprinkler system that irrigates the wetlands, predation by safari ants (Dorylus sp.), and/or pesticides in flushed dam sediments have contributed to the KST population extinction in the wild (Weldon \& du Preez 2004, Channing et al. 2006, Krajick 2006). Some of the KST specimens recovered from the 2003 mass mortalities in the Kihansi spray wetlands were diagnosed with chytridiomycosis (Weldon \& du Preez 2004), and chytridiomycosis in KST has been recorded in captivity at the Bronx Zoo (McAloose et al. 2008).

Chytridiomycosis caused by $B d$ is the single most important infectious amphibian disease that has commonly been associated with significant amphibian mortalities (Daszak et al. 1999, Longcore et al. 1999, Lips et al. 2006). Clinical signs of amphibian chytridiomycosis include abnormal posture, lethargy, and loss of the righting reflex, while gross morphological lesions consist of abnormal epidermal sloughing, cutaneous hemorrhages, and hyperemia of digital and ventral skin (Daszak et al. 1999). Bd disrupts cutaneous osmoregulatory function, leading to electrolyte imbalance, asystolic cardiac arrest, and death (Voyles et al. 2007, 2009). In addition, Bd produces toxic factors that inhibit protective host immune responses (Fites et al. 2013) and cause slower rehydration across the skin (Carver et al. 2010). In captivity, chytridiomycosis in amphibians can be treated with either chloramphenicol or itraconazole, the latter being the drug of choice (Forzán et al. 2008, Bishop et al. 2009, Young et al. 2012, Baitchman \&
Pessier 2013). A diagnostic polymerase chain reaction (PCR) assay for sensitive and specific detection of $B d$ has been developed using primers that amplify a region of the 5.8S ribosomal RNA gene and the flanking internal transcribed spacer regions (ITS1 and ITS2; Annis et al. 2004). Sequencing of this fragment of the 5.8S rRNA gene has been previously used to infer phylogeny of $B d$ (Gaertner et al. 2009, Goka et al. 2009, Schloegel et al. 2012, Bataille et al. 2013).

In November 2012, 351 toads died at the Kihansi captive breeding facility. Dead toads showed typical signs of chytridiomycosis, including epidermal sloughing and hyperemia of digital and ventral skin. The aim of this study was to perform confirmatory diagnosis of chytridiomycosis as the cause of death using PCR and subsequent 5.8S rRNA gene sequencing.

\section{MATERIALS AND METHODS}

\section{Study site, sample collection, and storage}

This study was conducted at the KST captive breeding facility located in Kihansi, Mlimba, Tanzania, following mass mortality of toads in November 2012. Seven dead toads were collected from each of the 7 affected cages, resulting in a total of 49 samples. Toads from each of the cages were pooled into sterile $50 \mathrm{ml}$ Falcon tubes and placed on ice for transport to the laboratory within $24 \mathrm{~h}$. Afterwards, $2 \mathrm{ml}$ of sterile phosphate-buffered saline (PBS) filtered through a $0.22 \mu \mathrm{m}$ Minisart syringe filter (Sartorius Stedim Biotech) were added into each tube with the toads. Each tube with the toads was inverted several times before PBS was pipetted out and collected into an Eppendorf tube. Washings from each of the tubes were pelleted by centrifugation at $13000 \times g$, and the pellet was resuspended in $200 \mu \mathrm{lPB}$ and stored at $-80^{\circ} \mathrm{C}$. A total of 38 Phrynobatrachus mababiensis frogs collected in the vicinity of the facility were swabbed in order to screen for $B d$. Before DNA extraction, $500 \mu \mathrm{l}$ PBS were added into the swabs followed by vortexing. Afterwards, swab suspensions were pelleted by centrifugation at $13000 \times g$, and the pellet was resuspended in $200 \mu \mathrm{l}$ PBS and stored at $-80^{\circ} \mathrm{C}$.

\section{DNA extraction, PCR amplification, and sequencing}

Toad washings and frog swab suspensions were thawed and $150 \mu \mathrm{l}$ of thawed washings and suspensions were incubated with $20 \mu \mathrm{l}$ of $20 \mathrm{mg} \mathrm{ml}^{-1}$ Pro- 
teinase $\mathrm{K}$ (Macherey-Nagel) at $55^{\circ} \mathrm{C}$ for $1 \mathrm{~h}$. DNA was then extracted from Proteinase K-digested washings and suspensions using QiaAmp nucleic extraction kits (Qiagen), following the manufacturer's instructions. During nucleic acid extraction and PCR, a culture (MCT08) of $B d$ from South Africa and PBS were used as positive and negative controls, respectively. PCR detection of $B d$ was performed using primers Bd1a and Bd2a that amplify the 5.8S rRNA gene and flanking ITS1 and ITS2, as previously described by Annis et al. (2004), using AccuPower PCR premix (Bioneer). The expected size of the PCR product using primers $\mathrm{Bd} 1 \mathrm{a}$ and $\mathrm{Bd} 2 \mathrm{a}$ is approximately 300 bp (Annis et al. 2004). PCR amplification was performed by an initial denaturation at $95^{\circ} \mathrm{C}$ for $10 \mathrm{~min}$ followed by 40 cycles of denaturation at $95^{\circ} \mathrm{C}$ for $45 \mathrm{~s}$, annealing at $60^{\circ} \mathrm{C}$ for $45 \mathrm{~s}$, and extension at $72^{\circ} \mathrm{C}$ for $1 \mathrm{~min}$, and a final extension at $72^{\circ} \mathrm{C}$ for 10 min using GeneAmp PCR systems 9700 (Applied Biosystems). Afterwards, PCR products were electrophoresed in a $2 \%$ agarose gel mixed with GelRed nucleic acid stain (Phenix Research Products) before visualization and imaging using a BioDoc-It imaging system (UVP). In order to verify the retrieval of fragments representing $B d$, PCR fragments were purified from agarose gels using a NucleoSpin gel and PCR clean-up kit (Macherey-Nagel) and subjected to dideoxynucleotide cycle sequencing by using Big Dye Terminator Cycle Sequencing Kit Version 3.1 (Applied Biosystems). Products from the dideoxynucleotide cycle sequencing reaction were purified by ethanol precipitation and separated on a 3500 Genetic Analyzer (Applied Biosystems).

\section{Nucleotide sequence similarity search}

The nucleotide sequence of the 5.8S rRNA $B d$ gene and partial flanking ITS1 and ITS2 regions obtained from the toads was submitted to GenBank, and compared with other sequences using BLASTn (Altschul et al. 1990). BLASTn compares nucleotide sequences to sequence databases and calculates the statistical significance of matches and can be used to infer functional and evolutionary relationships between sequences.

\section{Treatment of chytridiomycosis}

In an attempt to reduce mortalities, and due to the unavailability of itraconazole at the start of the outbreak, all toads at the facility were initially treated with a $0.002 \%$ chloramphenicol bath beginning on Day 18 after the start of the outbreak. Chloramphenicol was only used as a temporary measure while waiting for an itraconazole supply. On Day 23, chloramphenicol was replaced by a 10 min daily bath in amphibian Ringer's solution containing $0.1 \mathrm{mg} \mathrm{ml}^{-1}$ $(0.01 \%)$ itraconazole (Sporanox, Janssen Pharmaceutica) for $11 \mathrm{~d}$.

\section{RESULTS}

\section{KST mortality}

The Kihansi breeding facility housed 562 toads in 17 cages prior to the mortalities observed in late 2012. The highest mortalities were observed between 18 and 26 d after initial toad deaths in early November, and declined noticeably within $3 \mathrm{~d}$ of the itraconazole treatment (Fig. 1). Toad mortalities continued to increase throughout the treatment with chloramphenicol that lasted for $5 \mathrm{~d}$ (Fig. 1). Mortalities were observed in all 17 cages at the facility. By late December, when mortalities completely ceased, the captive breeding population had been reduced to 211 toads, with most survivors being juveniles and sub-adults.

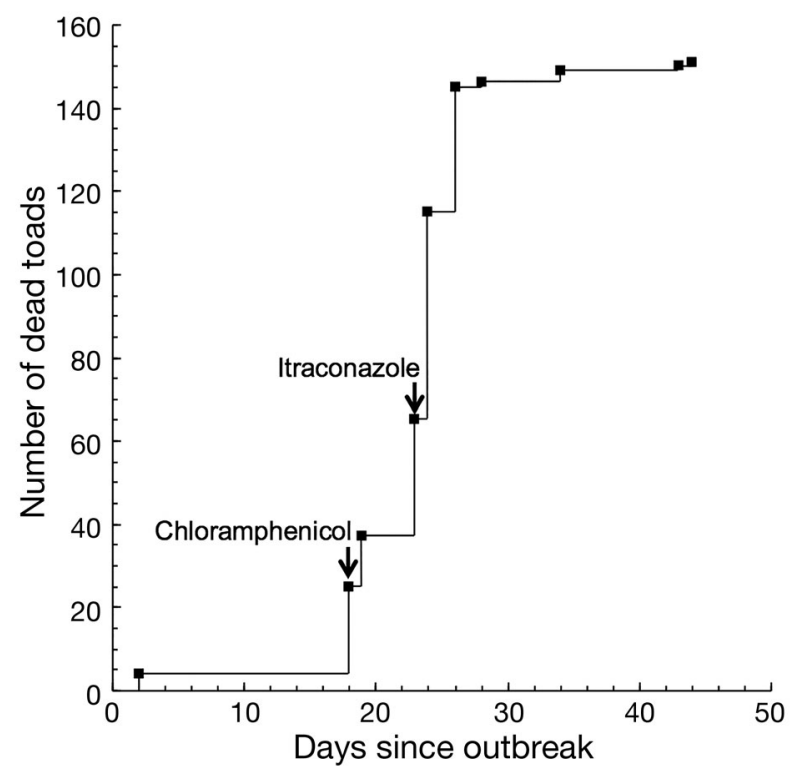

Fig. 1. Kihansi spray toad Nectophrynoides asperginis mortality at the Kihansi captive breeding facility. The cumulative number of dead toads is plotted against the days since the start of the chytridiomycosis outbreak. Mortalities of toads at the facility increased sharply with peak mortalities around Day 24 of the outbreak, followed by a sharp decrease $3 \mathrm{~d}$ after administration of itraconazole 


\section{Gross morphological lesions in dead toads}

Gross lesions in dead toads consisted of variable hyperemia (reddening) especially evident on the toe pads and the inguinal area, sloughing of the superficial epidermis of the feet, and abdominal skin discolouration (Fig. 2). The severity of the gross morphological lesions varied between individual toads.

\section{Diagnosis of $B d$ using PCR}

Agarose gel electrophoresis of PCR products revealed that all washings from 7 dead toads sampled were positive for $B d$, producing a $300 \mathrm{bp}$ PCR product as observed in the positive control. No PCR product was observed in the negative controls. In addition, PCR screening of wild Phrynobatrachus mababiensis from areas surrounding the facility revealed 9 out of 38 (24\%) frogs with $B d$.

\section{Similarity of KST Bd 5.8S rRNA sequence to GenBank sequences}

All 7 sequences of 5.8S rRNA and partial flanking ITS1 and ITS2 nucleotides of $B d$ from the toads were identical. The obtained nucleotide sequence was submitted to GenBank under accession number KF702314. BLASTn of KF702314 showed high identity with a number of published $B d$ sequences, although it was not $100 \%$ identical to any of the $B d$ sequences available in GenBank (Table 1). KF702314 showed the highest similarity to $B d$ from Ecuador, Japan, and the USA (Table 1).

\section{DISCUSSION}

We investigated the presence of $B d$ as a possible cause of mortalities in KST at the Kihansi captive breeding facility in November 2012. Morphological lesions and PCR results confirmed that chytridiomycosis caused the observed mortalities. Preliminary analysis showed that the $B d 5.8 \mathrm{~S}$ rRNA gene and partial flanking ITS1 and ITS2 nucleotide sequences obtained in this study were not $100 \%$ identical to any other $B d$ nucleotide sequences available in GenBank, although they were very similar to isolates from Ecuador, Japan, USA, Brazil, Korea, and South Africa (James et al. 2006, Goka et al. 2009, McCracken et al. 2009, Schloegel et al. 2012, Bataille et al. 2013). Possible introduction of $B d$ into the Udzungwa Mountains arising from stocking of rainbow trout Oncorhynchus mykiss has been speculated, although further fieldwork and re-sampling is necessary before conclusions can be reached about the nature and origin of $B d$ in this area (Moyer \& Weldon 2006).

Prior to treatment, mortalities of KST increased rapidly, indicating susceptibility and vulnerability to chytridiomycosis. Mortality of all KST following a chytridiomycosis outbreak has previously been observed at the Bronx Zoo (McAloose et al. 2008). This susceptibility, and the rapid deaths observed at the Kihansi facility, support the sharp population declines of wild toads observed in 2003 and their proposed chytridiomycosis-mediated extinction (Weldon \& du Preez 2004, Channing et al. 2006). Chloramphenicol and itraconazole have been successfully used in treating amphibian chytridiomycosis (Forzán et al. 2008, Tamukai et al. 2011, Young et al. 2012, Baitch-
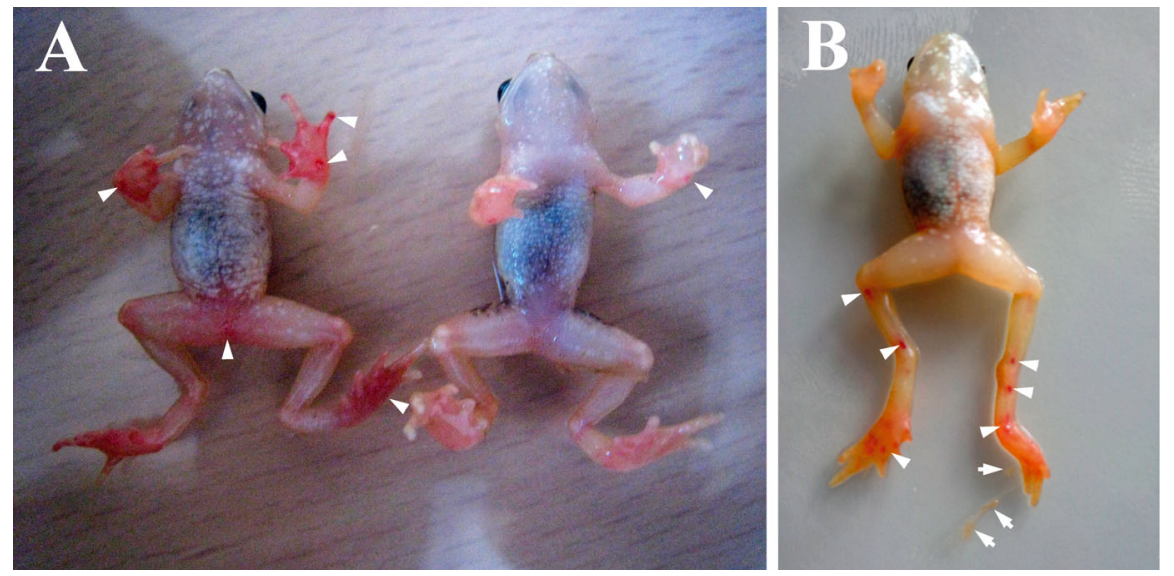

Fig. 2. Gross morphological lesions of chytridiomycosis in dead Kihansi spray toads Nectophrynoides asperginis. (A) Dead toads with variable hyperemia (reddening, indicated by arrowheads) that is especially evident on the toe pads and the inguinal area. The toad on the left shows greater hyperemia than the toad on the right. (B) A toad with hyperemia of the skin on the hind feet (arrowheads) and sloughing of the superficial epidermis of its left hind foot (arrows) 
Table1. Closest matches in GenBank (as determined by a BLASTn search) to the nucleotide sequence of the Batrachochytrium dendrobatidis $(B d)$ 5.8S rRNA gene and partial flanking ITS1 and ITS2 regions (filed under accession number KF702314) from Kihansi spray toads Nectophrynoides asperginis

\begin{tabular}{|c|c|c|c|c|c|c|}
\hline \multirow[t]{2}{*}{$B d$ isolate/strain } & \multirow{2}{*}{$\begin{array}{c}\text { Geographic } \\
\text { origin }\end{array}$} & \multirow{2}{*}{$\begin{array}{l}\text { Year of } \\
\text { isolation }\end{array}$} & \multicolumn{2}{|c|}{ Nucleotide identity (\%) } & \multirow{2}{*}{$\begin{array}{l}\text { Accession } \\
\text { no. }\end{array}$} & \multirow[t]{2}{*}{ Reference } \\
\hline & & & $\begin{array}{l}\text { ITS1-5.8S } \\
\text { rRNA-ITS2 }\end{array}$ & 5.8S rRNA & & \\
\hline MF20242 & Ecuador & $2004-2006$ & 250/251 (99) & $150 / 150(100)$ & FJ232006 & McCracken et al. (2009) \\
\hline $\mathrm{Bd}-21$ & Japan & 2008 & 250/251 (99) & $150 / 150(100)$ & AB435231 & Goka et al. (2009) \\
\hline $\mathrm{Bd}-30$ & Japan & 2010 & 249/251 (99) & $150 / 150(100)$ & AB723966 & Goka et al. unpubl. \\
\hline $\mathrm{Bd}-17$ & Japan & 2007 & 249/251 (99) & $150 / 150(100)$ & AB435227 & Goka et al. (2009) \\
\hline AD27_Bd_JG77_78 & USA & 2008 & 248/251 (99) & $150 / 150(100)$ & FJ373881 & Gaertner et al. unpubl. \\
\hline JEL648 clone L & Brazil & 2010 & $281 / 288$ (98) & $150 / 150(100)$ & JQ582893 & Schloegel et al. (2012) \\
\hline JEL648 clone B & Brazil & 2010 & 281/288 (98) & $150 / 150(100)$ & JQ582889 & Schloegel et al. (2012) \\
\hline CW34 clone D & South Africa & 2005 & 279/286 (98) & $150 / 150(100)$ & JQ582906 & Schloegel et al. (2012) \\
\hline $\mathrm{Bd}-20$ & Japan & 2008 & $248 / 252(98)$ & $150 / 150(100)$ & AB435230 & Goka et al. (2009) \\
\hline KR11 & Korea & $2010-2011$ & 246/252 (98) & $149 / 150(99)$ & JX983051 & Bataille et al. (2013) \\
\hline CW34 clone F & South Africa & 2005 & 285/293 (97) & $150 / 150(100)$ & JQ582927 & Schloegel et al. (2012) \\
\hline CW34 clone L & South Africa & 2005 & 285/293 (97) & $150 / 150(100)$ & JQ582916 & Schloegel et al. (2012) \\
\hline CW34 clone $\mathrm{T}$ & South Africa & 2005 & 284/293 (97) & $150 / 150(100)$ & JQ582937 & Schloegel et al. (2012) \\
\hline CW34 clone P & South Africa & 2005 & 284/293 (97) & 150/150 (100) & JQ582915 & Schloegel et al. (2012) \\
\hline CW34 clone G & South Africa & 2005 & 284/293 (97) & $150 / 150(100)$ & JQ582904 & Schloegel et al. (2012) \\
\hline CW34 clone J & South Africa & 2005 & 284/293 (97) & $150 / 150(100)$ & JQ582903 & Schloegel et al. (2012) \\
\hline JEL648 clone F & Brazil & 2010 & $280 / 288$ (97) & $149 / 150(99)$ & JQ582892 & Schloegel et al. (2012) \\
\hline JEL648 clone E & Brazil & 2010 & $280 / 288$ (97) & $150 / 150(100)$ & JQ582891 & Schloegel et al. (2012) \\
\hline JEL648 clone $\mathrm{N}$ & Brazil & 2010 & $280 / 288$ (97) & $149 / 150(99)$ & JQ582890 & Schloegel et al. (2012) \\
\hline JEL197 (AFTOL-ID 21) & USA & 1997 & $284 / 293$ (97) & $150 / 150(100)$ & AY997031 & James et al. (2006) \\
\hline
\end{tabular}

man \& Pessier 2013). In our study, toads were initially treated using chloramphenicol before itraconazole was made available. Chloramphenicol was administered for $5 \mathrm{~d}$, slowing the rate of deaths. It is possible that chloramphenicol would have been effective if the drug had been administered for a longer duration. Chloramphenicol has been shown to be effective against chytridiomycosis when administered for at least 2 wk (Young et al. 2012, Baitchman \& Pessier 2013). However, treatment of KST with itraconazole rapidly reduced mortalities, supporting previous observations of the high efficacy of this drug against chytridiomycosis in amphibians (Forzán et al. 2008, Tamukai et al. 2011, Baitchman \& Pessier 2013). However, peak mortalities of KST were observed between 1 and $72 \mathrm{~h}$ following treatment. The concentration of itraconazole used in this study is commonly administered (Baitchman \& Pessier 2013) but was 4 times higher than the concentrations recommended by Brannelly et al. (2012), and this may have contributed to drug-induced mortalities.

Previous surveillance of $B d$ in the Udzungwa Mountains found widespread distribution of $B d$ in amphibian populations (Moyer \& Weldon 2006). In the present study, $B d$ was found in $24 \%$ of amphibians in the vicinity of the facility using testing with $B d$-specific PCR. Therefore, $B d$ is present in the vicinity of the facility, and local infected amphibians may be a possible source of the chytridiomycosis outbreak at the facility. Sequencing of $B d$ from amphibians in the vicinity of the facility is required in order to affirm this possibility. Biosecurity measures at the facility have been implemented to prevent accidental introduction of disease, including restricted entry, changing of footwear, soaking of footwear in a hypochlorite foot bath, and wearing protective clothing and gloves while handling toads. It is recommended that strict biosecurity measures be adhered to by personnel at the facility in order to avoid further introductions of amphibian diseases to the captive KST population. Similarly, personnel monitoring the reintroduced KST in the Kihansi spray wetlands have to observe strict biosecurity measures in order to avoid introducing $B d$ to this only remaining wild KST population.

To our knowledge, this is the first study reporting the molecular characteristics of $B d$ isolated from captive KST at Kihansi within the Udzungwa Mountains of Tanzania. Further studies on the epidemiology of $B d$ in the Udzungwa Mountains are recommended in order to understand its origin, prevalence, and molecular characteristics in wild amphibian populations. This will be important for conservation of several endemic amphibian species in the Udzungwa Mountains, which are part of the Eastern Arc Mountains, a global biodiversity hotspot. 
Acknowledgements. This work was funded by the Tanzania Electric Supply Company Limited (TANESCO) through the Tanzania Energy Development and Access Project (TEDAP, IDA Credit No. 4960-TZ). The financing was part of the bridge arrangement to support continuation of the KST reintroduction plan, which was initiated under the Lower Kihansi Environmental Management Project (LKEMP, IDA Credit No: 3546-1-TA) coordinated by the National Environment Management Council (NEMC). The Bd MCT08 culture was a kind gift from Ché Weldon of the African Amphibian Conservation Research Group, School of Environmental Sciences and Development, Faculty of Natural Sciences, North-West University, Potchefstroom, South Africa. M.M. was supported by a scholarship from the Department of Zoology and Wildlife Conservation, College of Natural and Applied Sciences, The University of Dar es Salaam through TEDAP. The administrative assistance and technical guidance from Jane Kibbassa, Fadhila H.A. Khatibu, Amina Kibola, Felister M. Urasa, Cuthbert Nahonyo, Charles Msuya, William D. Newmark, and Mansur R. Hamdun are highly appreciated. Finally, we thank the anonymous reviewers for their many suggestions for improving the manuscript.

\section{LITERATURE CITED}

Altschul SF, Gish W, Miller W, Myers EW, Lipman DJ (1990) Basic local alignment search tool. J Mol Biol 215:403-410

Annis SL, Dastoor FP, Ziel H, Daszak P, Longcore JE (2004) A DNA-based assay identifies Batrachochytrium dendrobatidis in amphibians. J Wildl Dis 40:420-428

> Baitchman EJ, Pessier AP (2013) Pathogenesis, diagnosis, and treatment of amphibian chytridiomycosis. Vet Clin North Am Exot Anim Pract 16:669-685

> Bataille A, Fong JJ, Cha M, Wogan GO and others (2013) Genetic evidence for a high diversity and wide distribution of endemic strains of the pathogenic chytrid fungus Batrachochytrium dendrobatidis in wild Asian amphibians. Mol Ecol 22:4196-4209

> Bishop PJ, Speare R, Poulter R, Butler M and others (2009) Elimination of the amphibian chytrid fungus Batrachochytrium dendrobatidis by Archey's frog Leiopelma archeyi. Dis Aquat Org 84:9-15

Brannelly LA, Richards-Zawacki CL, Pessier AP (2012) Clinical trials with itraconazole as a treatment for chytrid fungal infections in amphibians. Dis Aquat Org 101:95-104

> Carver S, Bell BD, Waldman B (2010) Does chytridiomycosis disrupt amphibian skin function? Copeia 2010:487-495

> Channing A, Finlow-Bates KS, Haarklau SE, Hawkes PG (2006) The biology and recent history of the critically endangered Kihansi spray toad Nectophrynoides asperginis in Tanzania. J East Afr Nat Hist 95:117-138

Channing A, Howell K, Loader S, Menegon M, Poynton J (2009) Nectophrynoides asperginis. IUCN Red List of Threatened Species. Available at www.iucnredlist.org (accessed 20 September 2013)

> Daszak P, Berger L, Cunningham AA, Hyatt AD, Green DE, Speare R (1999) Emerging infectious disease and amphibian population declines. Emerg Infect Dis 5:735-748

> Fites JS, Ramsey JP, Holden WM, Collier SP and others (2013) The invasive chytrid fungus of amphibians paralyzes lymphocyte responses. Science 342:366-369

Forzán MJ, Gunn H, Scott P (2008) Chytridiomycosis in an aquarium collection of frogs: diagnosis, treatment, and control. J Zoo Wildl Med 39:406-411

Gaertner JP, Forstner MR, O'Donnell L, Hahn D (2009) Detection of Batrachochytrium dendrobatidis in endemic salamander species from central Texas. EcoHealth 6: 20-26

Goka K, Yokoyama J, Une Y, Kuroki T and others (2009) Amphibian chytridiomycosis in Japan: distribution, haplotypes and possible route of entry into Japan. Mol Ecol 18:4757-4774

$>$ James TY, Letcher PM, Longcore JE, Mozley-Standridge SE and others (2006) A molecular phylogeny of the flagellated fungi (Chytridiomycota) and description of a new phylum (Blastocladiomycota). Mycologia 98:860-871

Krajick K (2006) The lost world of the Kihansi Toad. Science 311:1230-1232

Lee S, Zippel K, Ramos L, Searle J (2006) Captive-breeding programme for the Kihansi spray toad Nectophrynoides asperginis at the Wildlife Conservation Society, Bronx, New York. Int Zoo Yearb 40:241-253

> Lips KR, Brem F, Brenes R, Reeve JD and others (2006) Emerging infectious disease and the loss of biodiversity in a Neotropical amphibian community. Proc Natl Acad Sci USA 103:3165-3170

> Longcore JE, Pessier AP, Nichols DK (1999) Batrachochytrium dendrobatidis gen. et sp. nov., a chytrid pathogenic to amphibians. Mycologia 91:219-227

McAloose D, Pramuk J, Raphael B, Calle P and others (2008) Mortality summary (2000-2007) in endangered captive Kihansi spray toads (Nectophrynoides asperginis). 57th Annual International Conference of the Wildlife Disease Association, Wildlife Disease Association, Edmonton, AB

McCracken S, Gaertner JP, Forstner MRJ, Hahn D (2009) Detection of Batrachochytrium dendrobatidis in amphibians from the forest floor to the upper canopy of an Ecuadorian Amazon lowland rainforest. Herpetol Rev 40: 190-195

Moyer DC, Weldon C (2006) Chytrid distribution and pathogenicity among frogs of the Udzungwa Mountains, Tanzania. The Critical Ecosystem Partnership Fund (CEPF) Small Grant Final Project Completion Report, Wildlife Conservation Society Tanzania, Iringa

Poynton JC, Howell KM, Clarke BT, Lovett JC (1998) A critically endangered new species of Nectophrynoides (Anura: Bufonidae) from the Kihansi Gorge, Udzungwa Mountains, Tanzania. Afr J Herpetol 47:59-67

Schloegel LM, Toledo LF, Longcore JE, Greenspan SE and others (2012) Novel, panzootic and hybrid genotypes of amphibian chytridiomycosis associated with the bullfrog trade. Mol Ecol 21:5162-5177

- Tamukai K, Une Y, Tominaga A, Suzuki K, Goka K (2011) Treatment of spontaneous chytridiomycosis in captive amphibians using itraconazole. J Vet Med Sci 73:155-159

> Voyles J, Berger L, Young S, Speare R and others (2007) Electrolyte depletion and osmotic imbalance in amphibians with chytridiomycosis. Dis Aquat Org 77:113-118

> Voyles J, Young S, Berger L, Campbell C and others (2009) Pathogenesis of chytridiomycosis, a cause of catastrophic amphibian declines. Science 326:582-585

Weldon C, du Preez LH (2004) Decline of the Kihansi spray toad, Nectophrynoides asperginis, from the Udzungwa mountains, Tanzania. Froglog 62:2-3

Young S, Speare R, Berger L, Skerratt LF (2012) Chloramphenicol with fluid and electrolyte therapy cures terminally ill green tree frogs (Litoria caerulea) with chytridiomycosis. J Zoo Wildl Med 43:330-337 